\title{
Synthesis and evaluation of surfactants with functional derivatives as additives for improvement of the mechanical and thermal properties of drinking water pipes
}

\author{
Shymaa M. Mahmoud ${ }^{2}$, Nadia G. Kandile ${ }^{1,}$, Maha M. El shafei ${ }^{2}$, \\ Amr H. Mohamed ${ }^{2}$ \\ 1. Chemistry Department Faculty of Women, Ain shams University,Heliopolis,Cairo,Egypt \\ 2. Housing \&Building National Research Center,Giza,Egypt
}

\begin{abstract}
.
In the present study, some thiol surfactants were prepared. Polyester / (nano bentonite) nano composite (A), polyester/(5\% nano Bentonite) / thiol surfactant (I) nano composite (B), polyester / (5\% nano Bentonite)/thiol surfactant (II) nano composite (C) and Polyester/(5\% nano Bentonite)/thiol surfactant (III) nano composite D were fabricated. The mechanical, thermal properties and morphological structure of fabricated composites were studied. The results showed that nano Bentonite powder / polyester composite improve these properties at $5 \%$ weight and begins to weaken as the filling ratios increased. However using thiol surfactants as additives to polyester / (nano bentonite) nano composites improve the thermal and mechanical properties of nano composites. But nano composite (D) gave the optimum thermal and mechanical properties which can be used in manufacture of drinking water pipes.
\end{abstract}

Keywords: Nano composite; surfactant, mechanical and thermal properties ,drinking water pipes.

\section{Introduction}

Polyester resins are one of the most important matrix materials which can be used in the manufacture of glass fiber reinforced composites [Zaske, O. C., Goodman,H. S., 1998]. For many years, polyester composites have been used in very varied technologies, like naval constructions, off-shore applications, water pipes, building construction, automotive applications , etc.[ Baudry,A. J., Dufay, N. R. ,et al., 1998], [ Rebeiz,K. S., 1996],

[Peter,J. S., Andrew, J. P., et al.,2006], [Peter, J. S., Michael, S. J., et al.,2006], [Ayman,M. A., Ashraf, M. E., et al.,2007] and [Lin , S. P., Shen, J. H., et al.,2008]. Polyester resins exhibit several useful characteristics due to the high degree of cross-linking between individual polymer chains [Matthews,F.L. Rawlings, R. D.,1999].

*Corresponding author email: chem.shymaamahmoud@gmail.com 
Polymer materials have many of benefits such as ease of production, lightweight and often ductile nature so there can be used in industry. However, they have some disadvantages, such as low modulus and strength compared to metals and ceramics. We can improve their properties to overcome these problems so natural materials can used such as clay, chrysotile and lingo cellulosic fibers as filler in fabrication of polymer nano composites [Varlot K., Reynaud, E., et al.,2001] and [Almansoori, A., Seabright, R., et al., 2017].

Nano composites are considered as the next industrial revolution materials which have a high performance material exhibit unusual property combinations. Applications of nano composites offer new technology and business opportunities for several sectors of the plastics, aerospace, automotive, electronics and biotechnology industries[Satyanarayana, K.G., Camargo, P. H.C., et al.,2009] and[Abulyazied, D. E. , Mokhtar ,S. M. et al.,2014].

Polymer nano composites are materials consisting of addition of particals at nano-scale which disperse in polymer to give a significant improvement of properties when compared to the base polymer[Lanciano, G.; Greco, A.; Maffezzoli, A.,et al., 2009], [Greco, A., Esposito Corcione, C., et al.,2010], [Corcione,C.E., Cavallo, A. , et al.,2011], [Calò, E., Massaro, C., Terzi,R., et al.,2012] and [Greco, A., Maffezzoli, A., et al.,2012]. Both thermoplastic as well as thermoset based clay nano composites have been widely studied, showing that in most cases improved the properties [Indennidate, L., Cannoletta, D ., et al.,2010], [Greco, A., Corcione, C.E., et al.,2010] and [Corcione, C.E., Mensitieri, G. et al. , 2009]. For this reason, academic research focuses on alternative materials for the production of polymer nano composites. These include addition of organic fillers [Frigione, M., Calò, E., J. ,2008], [Corcione ,C.E., Frigione, M., 2009] and [Di Lorenzo, M.L., Frigione, M., 1997]or use of different types of inorganic nano fillers such as clays have gained interest due to their exceptional properties like higher mechanical strength and thermal resistance of polymeric materials. These properties could further be improved by incorporating a certain amount of clay in the polymeric materials [Martone, A., Grassia, L., et al.,2012], [Monti, M., Natali, M., Torre, L. et al.,2012], [Monti, M., Natali M., et al.,2011] and[Terenzi, A., Vedova, C., et al.,2008].

In this work, we use surfactants with functional derivatives as additive of nano composites for improvement of the mechanical and thermal properties of drinking water pipes. So we study the behavior of pure resin (polyester), nano bentonite (clay) and organo clay powders. Static tensile, compressive and flexural tests are first carried out on polyester and (nano bentonite (clay) and organo clay)/polyester composites to evaluate the mechanical properties. Also the thermal gravimetric analyses (TGA) carried out on all fabricated nano composites to evaluate their thermal properties. 


\section{Experimental}

\subsection{Materials and Chemicals}

\subsubsection{Materials}

The resins used in this study was o-phthalic polyester resin obtained from Arab Company for Developed Materials of Egypt, it with medium viscosity as supplied by the manufacture. In addition, Bentonite was obtained from Beni suef /Egypt region. The raw bentonite with elemental composition contained montmorillonite as major element was used as filler material.

\subsubsection{Chemicals}

Chemicals used in this study and their specifications were illustrated in Table 1.

Table 1. Chemicals used in this study

\begin{tabular}{|l|l|l|}
\hline \multicolumn{1}{|c|}{ Compound } & \multicolumn{1}{|c|}{ Source } & Purity \\
\hline 2-Mercapto pyridine & Aldrich & $99 \%$ \\
\hline 1-Bromo decane & Riedel-deHaen & $97 \%$ \\
\hline 1-Bromo dodecane & Riedel-deHaen & $97 \%$ \\
\hline 1-Bromo hexadecane & Riedel-deHaen & $97 \%$ \\
\hline Acetone & Bio.chem & $99 \%$ \\
\hline Benzene & Adwic & $99.5 \%$ \\
\hline Petroleum ether & Adwic & $60-80 \%$ \\
\hline
\end{tabular}

\subsection{Preparation}

\subsubsection{Synthesis of heterocyclic surfactants (cationic thiol surfactants I,II and III) [Azzam,} E. M. S., Sami, R. M., et al.,2012]

A mixture of alkyl halides with different alkyl chain lengths of ( $0.02 \mathrm{~mol}, 4.42 \mathrm{gm})$ of 1-bromo decane, $(0.02 \mathrm{~mol}, 4.98 \mathrm{gm})$ of 1 - bromo dodecane and $(0.02 \mathrm{~mol}, 6.1 \mathrm{gm})$ of 1 - bromo hexadecane and $(0.02 \mathrm{~mol}, 2.22 \mathrm{gm})$ of 2-mercapto pyridine in acetone $(20 \mathrm{ml})$ was refluxed at $40^{\circ} \mathrm{C}$ for 5 hour. The reaction mixture was concentrated to evaporate acetone. The obtained precipitate was crystallized using mixture of benzene and petroleum ether $60-80 \%$, then dried to obtain cationic thiol surfactants 1-decane,dodecane and hexadecane 2-mercapto pyridine-1ium bromide (I,II and III) respectively as shown in Fig.1. 
Where

Cationic surfactant (I) with yellow crystals, m.p. $92^{\circ} \mathrm{C}$, yield $87.3 \%$, M.F. $\mathrm{C}_{15} \mathrm{H}_{26} \mathrm{NSBr}$, Cationic surfactant (II) with pale yellow crystals, m.p. $96^{\circ} \mathrm{C}$, yield $90.4 \%$, M.F. $\mathrm{C}_{17} \mathrm{H}_{30} \mathrm{NSBr}$, Cationic surfactant (III) with white crystals , m.p. $94^{\circ} \mathrm{C}$, yield $88.8 \%$, M.F. $\mathrm{C}_{21} \mathrm{H}_{38} \mathrm{NSBr}$.

\subsubsection{Preparation of Nano Bentonite}

Nano-particles of bentonite have been prepared by nano-grinding bentonite as crushed to finer particles and sundried for 5 days to ease pulverizing and sieving. Then was ground to powder with the aid of mortar and pastle, and then sieved with a rota shaker to obtain $63 \mu$ fractions to Suit API specification for local bentonite [Abdou, M.I., El-Sayed Ahmaed, H., 2011] and

[Sharma,U. A. Suri, M. Mukul, 2004] Nano-bentonite was prepared by crushing the local bentonite with the aid of a planetary ball mill PM 400 .The chemical analysis of bentonite powder and Nano bentonite powder as shown in Table 2.

Table 2: Chemical Analysis of Bentonite powder and Nano Bentonite Powder

\begin{tabular}{|c|c|c|}
\hline Material & Bentonite \% & Nano bentonite \% \\
\hline $\mathrm{LOI}^{*}$ & $\mathbf{1 3 . 4 0}$ & $\mathbf{1 0 . 2 0}$ \\
\hline $\mathrm{Na}_{2} \mathrm{O}$ & $\mathbf{1 . 4 6}$ & $\mathbf{2 . 3 7}$ \\
\hline $\mathrm{MgO}$ & $\mathbf{1 . 3 9}$ & $\mathbf{1 . 2 7}$ \\
\hline $\mathrm{Al}_{2} \mathrm{O}_{3}$ & $\mathbf{1 7 . 6 0}$ & $\mathbf{1 6 . 1 0}$ \\
\hline $\mathrm{SiO}_{2}$ & $\mathbf{4 2 . 1 0}$ & $\mathbf{4 8 . 3 0}$ \\
\hline $\mathrm{P}_{2} \mathrm{O}_{5}$ & $\mathbf{0 . 2 5}$ & $\mathbf{0 . 1 8}$ \\
\hline $\mathrm{SO}_{3}$ & $\mathbf{3 . 4 1}$ & $\mathbf{3 . 5 9}$ \\
\hline $\mathrm{Cl}$ & $\mathbf{1 . 2 1}$ & $\mathbf{0 . 3 1}$ \\
\hline $\mathrm{K}_{2} \mathrm{O}$ & $\mathbf{0 . 7 0}$ & $\mathbf{1 . 1 8}$ \\
\hline $\mathrm{CaO}$ & $\mathbf{6 . 7 9}$ & $\mathbf{5 . 9 4}$ \\
\hline $\mathrm{TiO} 2$ & $\mathbf{0 . 9 2}$ & $\mathbf{1 . 2 0}$ \\
\hline $\mathrm{MnO}$ & $\mathbf{0 . 1 0}$ & $\mathbf{0 . 1 0}$ \\
\hline $\mathrm{Fe} \mathrm{O}_{3}$ & $\mathbf{1 0 . 6 1}$ & $\mathbf{9 . 1 6}$ \\
\hline $\mathrm{TOTAL}$ & $\mathbf{9 9 . 9 4}$ & $\mathbf{9 9 . 9 0}$ \\
\hline
\end{tabular}

* loss of ignition

\subsection{Fabrication of nanocomposite}

Firstly, the drying conditions of filler is known to play a crucial effect on the process results, since nano bentonite is hydrophilic and the moisture can cause significant decrease in the thermal stability of nanobentonite and as a result decrease the synergistic properties between the polyester and nano bentonite. Thus, nano bentonite was dried at $80^{\circ} \mathrm{C}$ before used in fabricating with polyester. Addition of cationic thiol surfactants (I,II and III) to nano bentonite give organo clay (I,II and III) respectively. 
A variety of fabricating nano composites specimens were prepared according to Table $\mathbf{3}$. All fabricated nano composites were then left for 24 hour at room temperature, then specimens can be removal and the test specimens of required sizes were cut out from the sample sheet.

Table 3: Fabrication of nano composite specimens

\begin{tabular}{|c|c|c|}
\hline $\begin{array}{c}\text { Group } \\
\text { No }\end{array}$ & Material & $\begin{array}{c}\text { Nano Bentonite } \\
\%\end{array}$ \\
\hline 1 & Polyester resin & 0 \\
\hline 2 & $\begin{array}{c}\text { (Polyester/ } \\
\text { Nano Bentonite) } \\
\text { Nano composite (A) }\end{array}$ & $\begin{array}{c}2 \\
5 \\
10\end{array}$ \\
\hline 3 & $\begin{array}{c}\text { (Polyester/ } \\
\text { (Nano Bentonite } \\
\text { Thiol surfactant I) } \\
\text { Nano composite }(\mathrm{B})\end{array}$ & 5 \\
\hline 4 & $\begin{array}{c}\text { (Polyester/ } \\
\text { Nano Bentonite } \\
\text { Thiol surfactant II) } \\
\text { Nano composite } \quad(\mathrm{C})\end{array}$ & 5 \\
\hline 5 & $\begin{array}{c}\text { (Polyester/ } \\
\text { Nano Bentonite } \\
\text { Thiol surfactant III) } \\
\text { Nano composite (D) }\end{array}$ & 5 \\
\hline
\end{tabular}

\subsection{Testing}

\subsubsection{Mechanical Properties}

The prepared test specimens were subjected to static tensile, compression and flexural tests. All tests were performed at room temperature of $23^{\circ} \mathrm{C}$. In each test, five samples were tested and the average value was tabulated were carried out using $100 \mathrm{KN}$ computerized AG-Shimadzu-Autograph Universal Testing Machine at testing speed was $1 \mathrm{~mm} / \mathrm{min}$.

Tensile testing samples were prepared in dumbbell shapes with dimensions as per [ASTM D638-14]. The samples were loaded in tension at a cross-head speed of $1 \mathrm{~mm} / \mathrm{min}$ to determine their tensile behavior. A three point flexural test was carried out to determine the inter laminar shear strength (ILSS) of the samples as per [ASTM D790-17].

The slow flexural test specimen has a rectangular cross-section, $9 \mathrm{~mm}$ width and thickness $4 \mathrm{~mm}$ and $100 \mathrm{~mm}$ length. Compressive test was carried out using testing machine at load rate of approximately $0.2 \mathrm{~N} / \mathrm{mm}^{2} \mathrm{~S}$. The specimens were taken according to the standard specification [ASTM D695 - 15] . The compression test specimen has a height equal to width and a width $20 \mathrm{~mm}$. 


\subsubsection{Thermal properties analysis}

The thermal characteristics of the polyester/filler fabrication nano composites were studied using thermal gravimetric analysis (TGA) (Shimadzu TGA-50). TGA was used to investigate thermal decomposition behavior of the nano composite fabrication.

\subsubsection{Morphology analysis}

The morphology of fabricated nano composites was studied using Inspect s model scanning electron microscope (SEM). SEM also used for studied the dispersion of filler particles in the fabrication of nano composites

\section{Results and Discussion}

In this study, a mixture of thiol surfactants based on 2-mercaptopyridine with alkyl halides with different alkyl chain lengths (I,II and III) were prepared according to the method in expermental part as illustrated in Fig. 1.

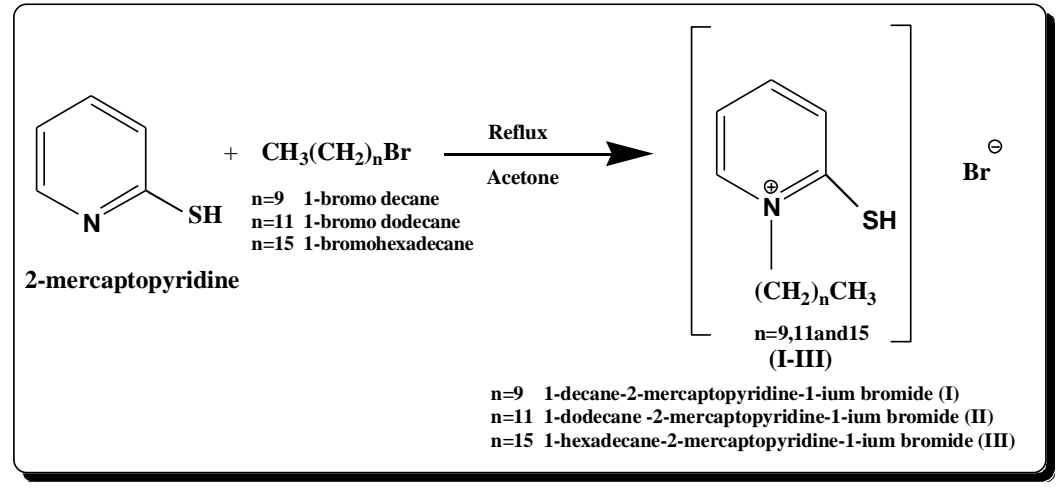

Fig. 1 Synthesis of the cationic thiol surfactants (I,IIandIII)

A prepared thiol surfactants used as additive in the fabrication of polyester nanocomposites to evaluate their mechanical and thermal properties to be applied in the manufacture of drinking water pipes.

\subsection{Mechanical Properties}

The mechanical properties of all fabrication nano composites are shown in Table 4.

Tensile strength (TS) increased with increasing amount of nano bentonite at $2 \%$ weight, $5 \%$ weight and $10 \%$ weight about $2.5 \%, 10 \%$ and $1.6 \%$ respectively compared with polyester resin which showed maximum at 5\%weight, so we using thiol surfactants as additives to nano composites at $5 \%$ weight.The tensile strength increased for 5\% weight of (organo clay I, organo clay II and organo clay III) compared with polyester resin. The tensile strength of polyester base matrix was improved by about $11 \%, 11.7 \%$ and $12.5 \%$ respectively

Flexural strength (FS) increased with increasing amount of nano bentonite at $2 \%$ weight, $5 \%$ weight and $10 \%$ weight about $3.3 \%, 11.94 \%$ and $6.5 \%$ respectively compared with polyester resin which showed maximum at $5 \%$ weight, so we used thiol surfactants as additives to nano composites at $5 \%$ weight.The flexural strength increased for $5 \%$ weight of (organo clay 
I, organo clay II and organo clay III) compared with polyester resin. The iimprovement of the flexural strength of polyester base matrix was about $12.23 \%, 12.66 \%$ and $12.94 \%$ respectively.

Also the same trend was clear for compressive strength (CS) which increased at $2 \%$ weight, $5 \%$ weight and $10 \%$ weight about $8.5 \%, 20 \%$ and $6 \%$ respectively compared with polyester resin which showed maximum at 5\%weight, so we used thiol surfactants as additives to nano composites at 5\% weight. The compressive strength increased for $5 \%$ weight of (nano bentonite, organo clay I, organo clay II and organo clay III) compared with polyester resin. The improvement of the compressive strength of polyester base matrix was about $20.14 \%, 20.28 \%$ and $20.42 \%$ respectively.

It was observed that, the mechanical properties were optimized at $5 \%$ weight organo clay III content.

Table 4: Mechanical Properties of Fabrication of Nano composites

\begin{tabular}{|c|c|c|c|c|}
\hline Material & $\begin{array}{c}\text { Nano } \\
\text { bentonite } \\
\text { (wt. \%) }\end{array}$ & $\begin{array}{c}\text { Tensile } \\
\text { Strength } \\
\text { (MPa) }\end{array}$ & $\begin{array}{c}\text { Flexural } \\
\text { Strength } \\
\text { (MPa) }\end{array}$ & $\begin{array}{c}\text { Compressive } \\
\text { Strength } \\
\text { (MPa) }\end{array}$ \\
\hline Polyester & $0 \%$ & 60 & 695 & 140 \\
\hline $\begin{array}{c}\text { (Polyester/ Nano Bentonite) } \\
\text { Nano Composites (A) }\end{array}$ & $2 \%$ & 61.5 & 718 & 152 \\
\cline { 2 - 5 } & $5 \%$ & 66 & 778 & 168 \\
\cline { 2 - 5 } & $10 \%$ & 61 & 740 & 149 \\
\hline $\begin{array}{c}\text { (Polyester / Nano Bentonite/ } \\
\text { Thiol surfactant I) } \\
\text { Nano Composites (B) }\end{array}$ & $5 \%$ & 66.5 & 780 & 168.2 \\
\hline $\begin{array}{c}\text { (Polyester / Nano Bentonite)/ } \\
\text { Thiol surfactant II) } \\
\text { Nano Composites (C) }\end{array}$ & $5 \%$ & 67 & 783 & 168.6 \\
\hline $\begin{array}{c}\text { (Polyester / Nano Bentonite/ } \\
\text { Thiol surfactant III) } \\
\text { Nano Composites (D) }\end{array}$ & $5 \%$ & 67.5 & 785 & 168.4 \\
\hline
\end{tabular}




\subsection{Thermal gravimetric analysis (TGA)}

The thermo gravimetric analysis showed the weight - loss of the nano composites at different weight $(0 \%, 2 \%, 5 \%$, and $10 \%)$ of nano bentonite as shown in Fig.2.

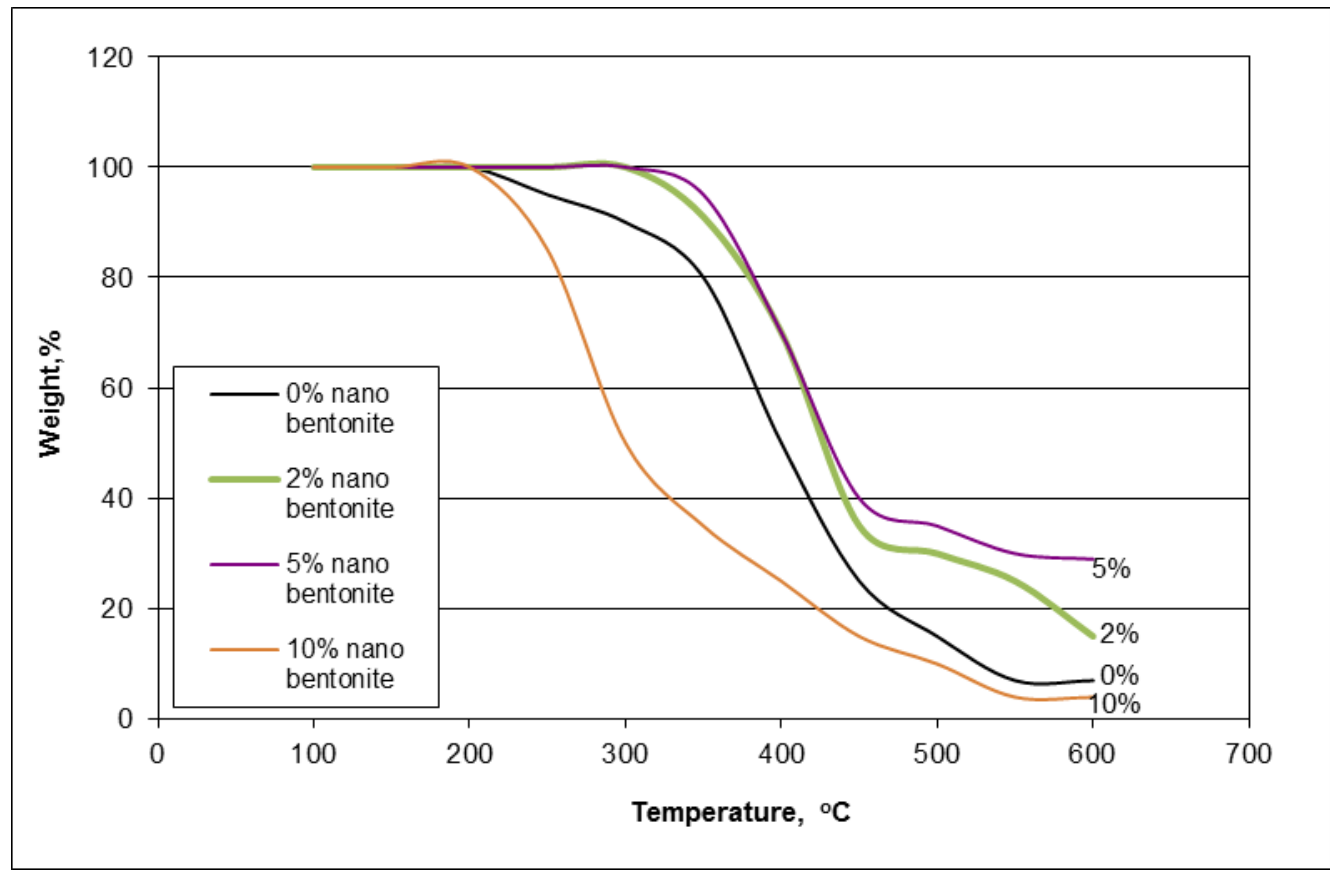

Fig.2 TGA of nano bentonite/ polyester nano composites

TGA curves showed the weight loss of pure polyester show no change up to $200{ }^{\circ} \mathrm{C}$, after $200^{\circ} \mathrm{C}$ start weight loss change and then decomposition occur at $400{ }^{\circ} \mathrm{C}$ to weight loss $50 \%$ of original weight of polyester. It is clear that the decomposition temperature of the nano composite shifted towards higher temperatures by loading $2 \%$ of weight of nano bentonite, but loading $5 \%$ weight of nano bentonite shift to more higher temperature which indicating higher thermal stability of the nano composite due to high level of dispersion and improve thermal properties ,but after increasing up to $10 \%$ weight of nano bentonite shift towards lower temperature i.e. lower thermal stability due to high nano bentonite loading than $5 \%$ weight sample exhibits a structure having large nano bentonite aggregates, which act as stress concentrators.

It was observed that decomposition temperature of nano composite shifted towards higher temperature indicating higher thermal stability of nano composite up to $5 \%$ nano bentonite at $450^{\circ} \mathrm{C}$, which lower $50^{\circ} \mathrm{C}$ than pure polyester. So using thiol surfactant as additives to nano composites at $5 \%$ weight.

The thermal gravimetric analyses (TGA) of adding (nano bentonite, organo clay I, organo clay II and organo clay III) show increasing in decomposition temperature and weight loss constant up to $300{ }^{\circ} \mathrm{C}$ when compared with pure polyester resin as shown in Fig. 3 .

TGA curve showed adding the three thiol surfactants (I, II and III) to nano bentonite surface (organo clay I, organo clay II and organo clay III) respectively show increasing in decomposition temperature than nano bentonite only, which improved of thermal stability of nano composites. 
It is clear that no significant change between two curves when adding thiol surfactants (I and II) to nano bentonite (organo clay I and II), but adding thiol surfactant III to nano bentonite (organo clay III) show higher thermal stability than (organo clay I and organo clay II).

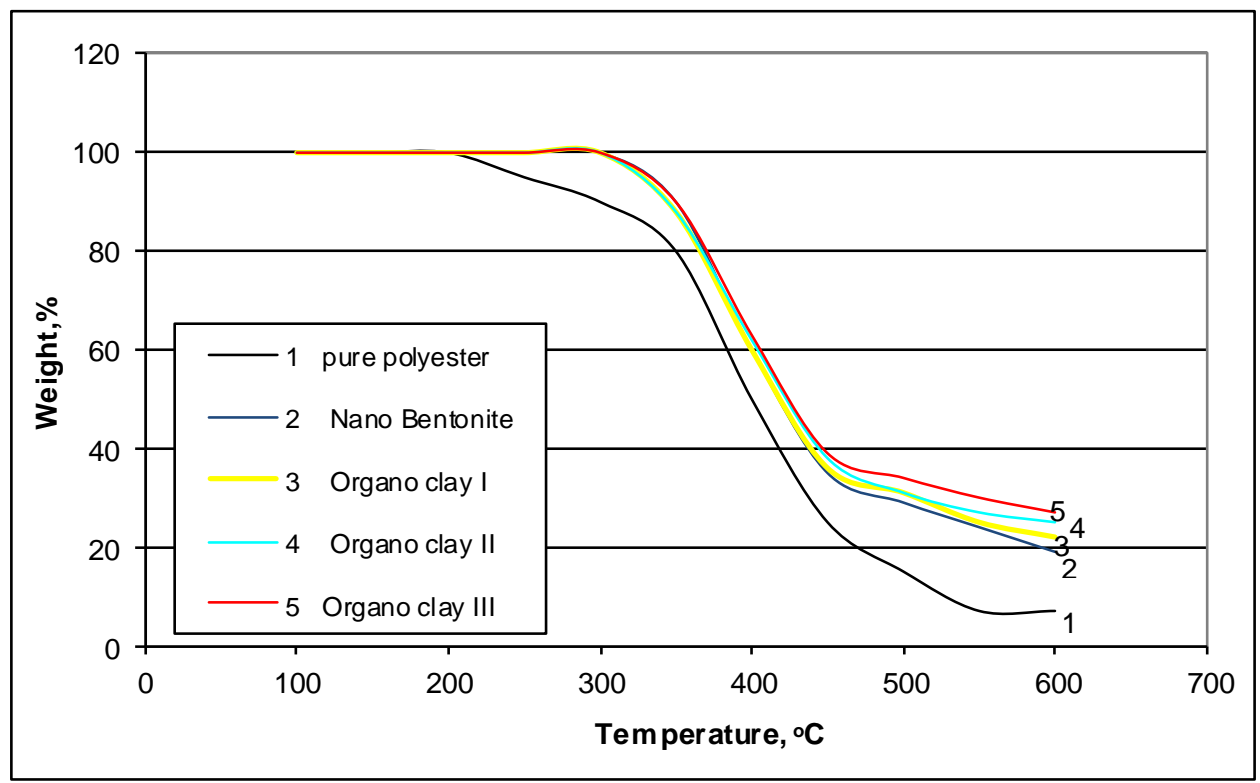

Fig.3 TGA of pure resin and nano composites containing different type of tested material at 5 $\%$ weight.

\subsection{Morphology Analysis}

Morphology analysis of all fabrication nano composite are shown in Fig.4 (a-g). As shown in Fig.4 a the morphology of pure polyester resin is very smooth and amorphous with small wider crack propagation lines. Adding 2\% nano bentonite shows distances between the crack propagation lines are much smaller than the pure polyester due to nano bentonite start to mix with polyester but without good dispersion between them as shown in Fig.4 b. But by increasing nano bentonite to $5 \%$ wt. show a crack propagation lines disappeared but observe some flakes on the surface as show in Fig.4 c.

On the other hand nano composite containing $10 \mathrm{wt} . \%$ of nano bentonite particles as shown in Fig.4 d shows poor adhesion and bonding were observed were not dispersed well and large aggregates on this surface results in easy crack propagation due to increase in nano bentonite particles correspondingly increases viscosity of the modified polyester which act as stress concentrators on the nano composite surface. This causes localized stresses on the surface of the clay leading to failure at mechanical properties at $10 \mathrm{wt} . \%$ of nano bentonite.

In case of adding of surfactants (I, II and III) to 5\%wt. nano bentonite, it showed disappear of all flakes and decrease in interlayer space but observe a large accumulation decrease by increase alkyl chain of surfactant as shown in Fig.4 $(\mathbf{e}, \mathbf{f}, \mathbf{g})$ respectively. So in case of adding the longest alkyl chain (surfactant III) to 5\%wt. nano bentonite shows surface with uniform appearance and more smooth structure which give maximum improvement of mechanical and thermal properties as shown in Fig.4 g. 
J. Sci. Res. Sci.,Vol.(35), 2018
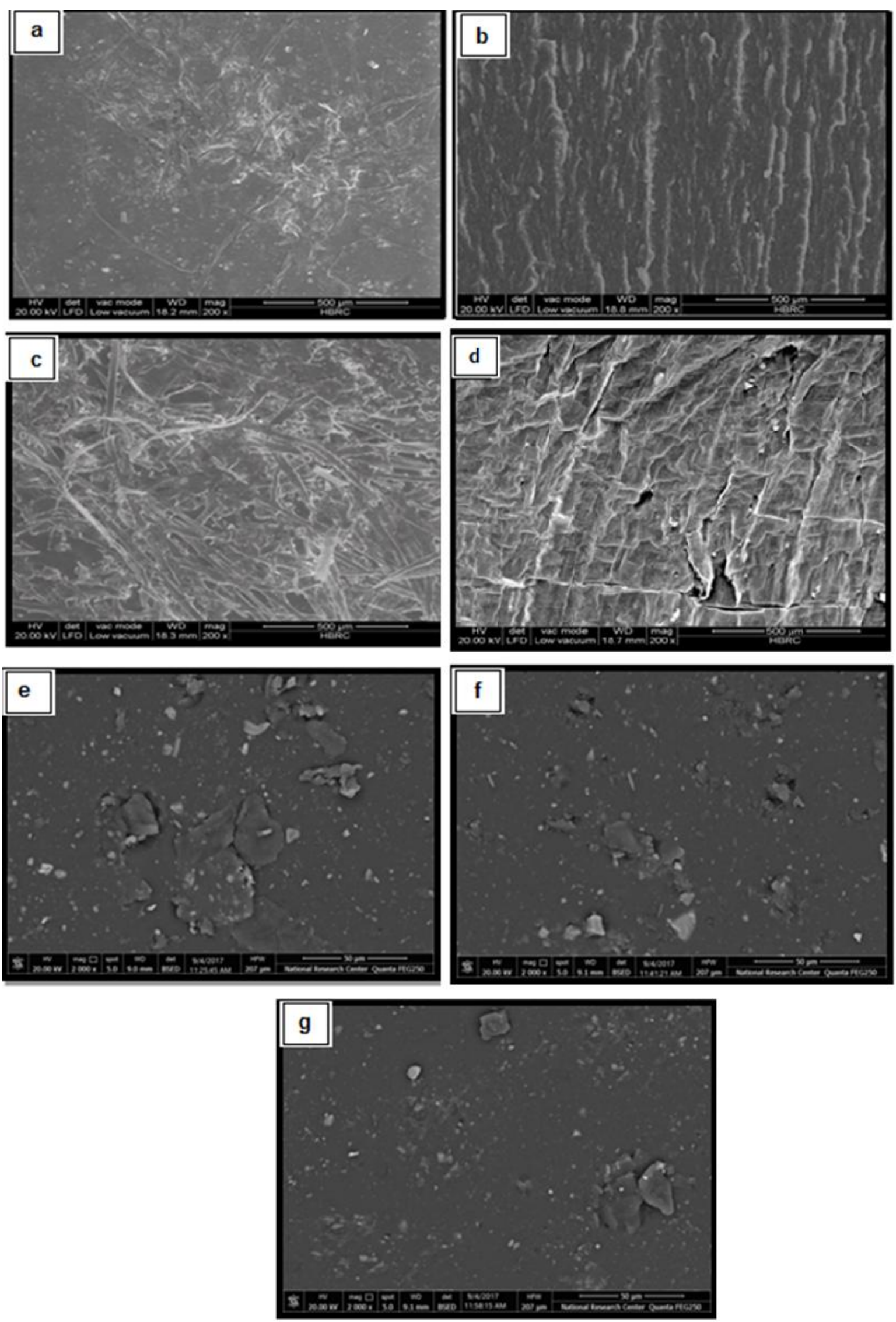
Fig.4 Morphology of nano composites at (a) pure polyester (b) 2\%wt. nano bentonite (c) $5 \%$ nano bentonite (d) $5 \%$ wt. organo clay I (e) $5 \%$ wt. organo clay II (f) $5 \%$ wt. organo clay III (g) $10 \%$ wt. nano bentonite

\section{Conclusions}

In this paper, thiol surfactants were prepared from the reaction of 2-mercaptopyridine with different alkyl halides with different alkyl chain lengths.

The mechanical, thermal and morphological properties of all fabricated nano composites were studied. From the results obtained the following conclusions were reported:

1. It was observed that, mechanical properties were optimized at $5 \mathrm{wt} \% \%$ organo clay III content in fabrication nano composite (D). When compared with pure polyester, it gave the following results. Tensile strength showed a $12.5 \%$ increase, flexural strength showed a $12.94 \%$ increase while the compressive strength showed a $20.42 \%$ increase in strength.

2. The thermal gravimetric analysis (TGA) showed decomposition behavior of adding (nano bentonite, organo clay I, organo clay II and organo clay III) at 5\% to polyester which show increasing in decomposition temperature and weight loss constant up to $300{ }^{\circ} \mathrm{C}$ when compared with pure polyester resin . It is clear that the best thermal stability of nano composite (D) which formed by adding thiol surfactant ( III) to 5\% weight nano bentonite.

3. Morphology analysis revealed that excellent adhesion and interfacing between the polyester and organo clay (III) is the main reason for optimum improvement of properties. Finally nano composite (D) improved the mechanical and thermal properties of nano composites which leads to raise the efficiency of polyester resin and can be applied in the manufacture of drinking water pipes.

\section{References}

Abdou, M.I., El-Sayed Ahmaed, H., Petrolum Sci. Technol. 29, 2220 (2011).

Abulyazied, D. E. , Mokhtar ,S. M. and Motawie, A.M. , J.of Appl. Chemistry, 7, 32(2014).

Almansoori, A., Seabright, R., Majewski, C., and Rodenburg, C., IOP Publishing IOP Conf. Series: Materials Science and Engineering, 195 ( 2017).

ASTM D638 , An ASTM designation number identifies a unique version of an ASTM standard test method for Tensile Properties of Plastics (2014).

ASTM D695 Standard Test Method for Compressive Properties of Rigid Plastics (2015).

ASTM D790 Standard Test Methods for Flexural Properties of Unreinforced and Reinforced Plastics and Electrical Insulating Materials (2017). 
Ayman,M. A., Ashraf, M. E., Reem,K. F. , Shymaa, M. E., Reactive and Functional Polymers, 67, 549 (2007).

Azzam, E. M. S., Sami, R. M., Kandile ,N. G., American Journal of Biochemistry, 2, 29 (2012).

Baudry,A. J., Dufay, N. R. and Mortaigne,B., Polymer Degradation and Stability, 61,441 (1998).

Calò, E., Massaro, C., Terzi,R., Cancellara A., Pesce, E., Rea,M., Greco, A., Maffezzoli, A., Gonzalez-Chi, P.I. and Salomi, A., Int. Polym. Process., , 27 ,370(2012).

Corcione,C.E., Cavallo, A. , Pesce, E. , Greco, A. and; Maffezzoli, A., Polym. Eng. Sci., 51,1280 (2011).

Corcione, C.E., Mensitieri, G. and Maffezzoli, A., Polym. Eng. Sci., 49,1708(2009).

Corcione ,C.E., Frigione, M., Polym. Test, 28 ,830 (2009).

Di Lorenzo, M.L., Frigione, M., J. Polym. Eng., 17, 429 (1997).

Frigione, M., Calò, E., J. Appl. Polym. Sci., 107,1744 (2008).

Greco, A., Corcione, C.E., Maffezzoli, A., Defect Diffus. Forum, 297, 422(2010).

Greco, A., Esposito Corcione, C., Strafella, A., Maffezzoli, A., J. Appl. Polym. Sci., 118,3666 (2010).

Greco, A., Maffezzoli, A., Calò, E., Massaro, C. and Terzi, R., J. Therm. Anal. Calorim. 109,1493(2012).

Indennidate, L., Cannoletta, D ., Lionetto, F., Greco, A. and Maffezzoli, A., Polym. Int., 59 , 486 (2010).

Lanciano, G.; Greco, A.; Maffezzoli, A.; Mascia, L. ,Effects of thermal history in the ring opening polymerization of CBT and its mixtures with montmorillonite on the crystallization of the resulting poly(butylene terephthalate),Thermochim. Acta,493: 61-67(2009).

Lin , S. P., Shen, J. H., Han, J.L ., Lee, Y. J., Liao, K. H., Yeh, J. T., Chang, F. C. and Hsieh,K.H, Composites Science \& Technology, 68, 709 (2008) .

Matthews,F.L. Rawlings, R. D.,: Composite Materials: Engineering and Science, Chapman \& Hall, London, (1999).

Martone, A., Grassia, L., Zarrelli, M., Giordano, M. and Amore, A.D., AIP Conf. Proc., $1459,347(2012)$. 
Monti, M., Natali, M., Torre, L. and Kenny, J.M., Carbon, , 50 , 2453 (2012).

Monti, M., Natali M., Petrucci, R., Kenny, J.M. and Torre, L., Polym. Compos., ,32 , 766 (2011).

Peter,J. S., Andrew, J. P., Edward, H. L., Nicholas,A. W. ,Chris D. R., Composites Part A: Applied Science and Manufacturing, ,37, 1747 (2006).

Peter, J. S., Michael, S. J., Nicholas, A. W., Chris,D. R., Composites Part A: Applied Science and Manufacturing, 37,1757 (2006) .

Satyanarayana, K.G., Camargo, P. H.C., and Wypych, F., Mat. Res. , 12,1 (2009).

Terenzi, A., Vedova, C., Lelli, G., Mijovic, J., Torre, L., Valentini, L. and Kenny, J.M., Compos. Sci. Technol., 68, 1862 (2008).

Sharma, U., Suri, A., Mukul,M., SPE J. 9,13 (2004) .

Rebeiz,K. S., Construction \& Building Materials, 10, 215 (1996).

Varlot K., Reynaud, E., Kloppfer, M.H., Vigier, G. and Varlet,J. ,J. Polym. Sci. Part B Polym. Phys., 39, 1360 (2001).

Zaske, O. C., Goodman,H. S., Prepolymer Polyester and Vinyl Ester Resins, in: Handbook of Thermoset Plastics,2nd Ed., Noyes Publication, Westwood (1998). 


\title{
الملخص باللغة العربية
}

تحضير وتقييم بعض المواد ذات النثاط السطحي ومشتقاتها المستخدمة كاضافه لتحسين الخواص إسياه الميكانيكية و الحرارية لمواسير مياه الثرب

\author{
شيماء محمود 2 ، نادية غريب قنديل1 ، مها الثافعي2² عمرو حسن2 ، \\ 1 قسم الكيمياء كلية البنات جامعة عين شمس \\ 2 المركز القومي لبحوث الاسكان والبناء
}

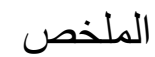

تناولت الدر اسة تحضير بعض مركبات عضوية ( مو اد ذات نشاط سطحي ) ـ وتم تحضير البولي استر

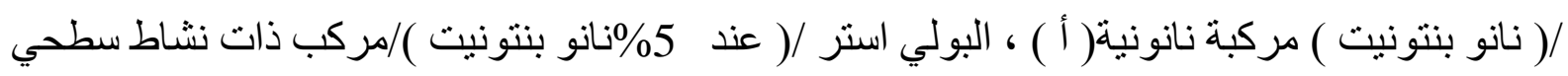

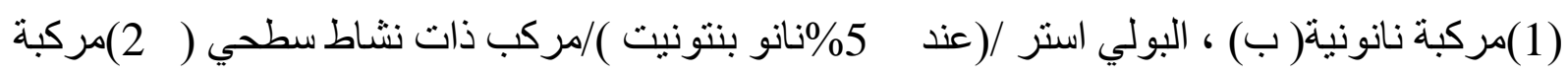

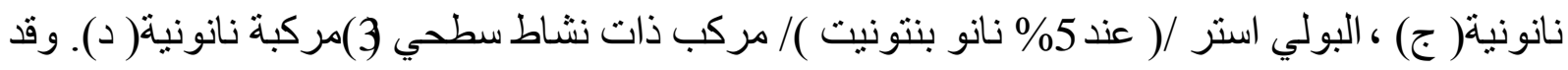

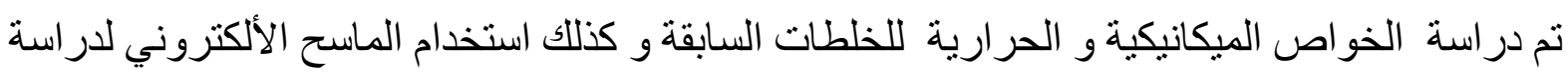
مورفولوجيا المو اد التي تم تحضير ها.و أظهرت النتائج أن المو اد المركبة التي تم تحضير ها من النانو بنتونيت /بولي استر قد حسنت الخواص عند نسبة5\% من النانو بنتونيت وتقل الخو اص بزيادة نسبة النانو بنتونيت. مما سبق يتضح أن استخدام المركبات ذات النشاط السطحي كاضافات الي البولي استر /( نانو

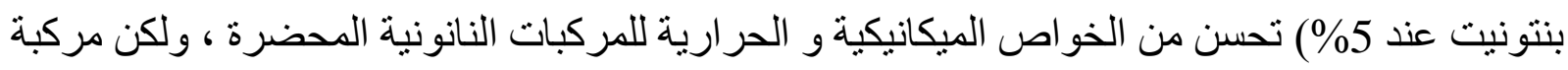
نانونية( د) اعطت اعلي خو اص ميكانيكية (قوة) وخو اص حر اريةوبذللك يمكن استخدامها في صناعة

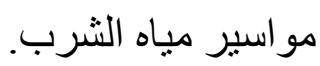

